\title{
A Study on the EFL Teachers' Awareness of Classroom Observation Criteria
}

\author{
Khalil Motallebzadeh ${ }^{1} \&$ Aynaz Samir $^{1}$ \\ ${ }^{1}$ English Department, Torbat-e-Heydarieh Branch, Islamic Azad University, Torbat-e-Heydarieh, Iran \\ Correspondence: Aynaz Samir, English Department, Torbat-e-Heydarieh Branch, Islamic Azad University, \\ Torbat-e-Heydarieh, Iran. E-mail: aynazsamir@yahoo.com
}

Received: August 25, 2016

Accepted: September 21, 2016 Online Published: November 23, 2016

doi:10.5539/ijel.v6n6p162

URL: http://dx.doi.org/10.5539/ijel.v6n6p162

\begin{abstract}
The aim of the present study was to investigate the Iranian EFL teachers' awareness of classroom observation criteria. To this end, 123 Iranian EFL teachers at several language institutes and universities participated in this study. The participants were selected through the convenience sampling method. The instrument used for data collection was a questionnaire for evaluating the criteria used for classroom observation. The reliability of the questionnaire was calculated through Cronbach Alpha. The data were collected in person and through email; they were analyzed through descriptive statistics, independent samples t-test, and the analysis of variance (ANOVA). The descriptive statistics indicated that an increase in teaching experience results in an increase in teachers' awareness of the classroom observation criteria. The independent samples t-test indicated that there was not a significant difference between gender and the teachers' awareness of classroom observation criteria. The results obtained from the ANOVA test indicated that there was no difference statistically in teachers' awareness of classroom observation criteria between the fields of study, and level of education. The result of ANOVA test showed that age had a significant impact on teachers' awareness of observation criteria. The findings of this study showed that a high percentage of Iranian EFL teachers are aware of the classroom observation criteria.
\end{abstract}

Keywords: classroom observation, observation criteria, EFL teachers, supervisor

\section{Introduction}

Investigating the annual performance of the teacher is the main aim of observing the teaching process in the classroom. Generally, the supervisors in each language institute use a standard observation checklist to fill it out during the observation of the teaching process. Then, the supervisor and the teacher discuss together the merits and demerits of the teacher's methodology in a briefing session during which some suggestions are offered to improve the teacher's performance. As such, the supervisor pays more attention to some items, such as the class management, the creation of engagement in the classroom context, the students' involvement, the students and the teacher's way of thinking, the use of books and course materials, the teaching techniques used by the teacher, and the attempts to find evidence of students' learning (Stoller, 1996). Nevertheless, classroom observation has not reached the place it deserves at English language institutes in Iran. Not much effort is made for the professional trainings of supervisors. Moreover, in this area the supervisor's personal idea plays a significant role and the observation criteria become personalized which leading to the teachers' dissatisfaction. In addition, there are different viewpoints regarding the role of supervisors and their performance; therefore, the criteria which have been presented for the observation of the teaching process are different. By becoming aware of classroom observation criteria, the teacher would better realize the prior criteria for observing the teaching process from the viewpoint of supervisors, whereas the criteria and approach through which their performance is evaluated also become clear. However, since only a few studies has been carried out in this area in Iran, further research is, indeed, needed to investigate the Iranian EFL teachers' awareness of the criteria used for classroom observation.

\section{Literature Review}

One of the requirements of language institutes is the presence of an efficient supervisor. The Lack of an efficient supervisor results in chaos at language institutes (Kimbrough \& Burkett, 1990). In language teaching institutes, the supervisor regularly observes the teachers' teaching methodology in order to train them and improve their teaching methodology (Allwright, 2014; Gebhard, 1990). In this sense, the supervisor is responsible for 
supervising and improving the teaching performance of teachers and colleagues in an educational context (Wallace, 1991). The supervisor should improve the teaching process and the efficiency of training without having a judgmental attitude (Alfonso, 1984, as cited in Widodo \& Zakaria, 2008). According to Wallace (1991), the supervisor is an individual who attempts to communicate with the teacher during the observation sessions. Through classroom observation, the supervisor gives a good opportunity to teachers to gain more information about their teaching performance (Cohen, Manion, \& Morrison, 2000; Mackey \& Gass, 2005). The goal of the observation is to reach a mutual agreement on employing better teaching methodologies; therefore, the supervisor listens to the teachers' problems and then suggests some solutions as such. In fact, the supervisor encourages teachers to employ new and alternative methods in order to promote and improve the teaching quality (Widodo \& Zakaria, 2008). In other words, the supervisor introduces a better teaching methodology to teachers, supports them to improve their teaching skills, and finally assesses the professional performance of teachers (Shantz \& Brown, 1999). The items evaluated by the supervisor during the observation include the lesson, general course objectives, the use of the book and supplementary learning materials in teaching, the teaching methodology, the degree of the mastery of the content, the teacher's clothing, the tone of the teacher's voice, the manner of starting and finishing the lesson, the maintenance of discipline in the classroom, and the students' motivation for learning (Gujjar, Ramzan, \& Bajwa, 2011).

Traditionally, observing the teaching process in language classrooms was part of evaluating the teacher's performance, where the supervisor was the head of the institute or one of the experienced teachers. In this sense, supervisors would usually observe the teaching and learning process following their personal ideas while their feedback was given for judging the teacher, not improving the quality of teaching and learning (Sheal, 1989). Traditionally, the supervisor would sit at the back of the classroom and observe the performance of an anxious teacher trying to satisfy the supervisor (Akbari, Gaffar, \& Tajik, 2006). On the other hand, the supervisor would check some items on the observation checklist and then s/he would decide whether a teaching method was appropriate or not. Following the classroom observation, the supervisor addressed some remarks on the teacher's methodology, and then the teacher attempted to compensate for the drawbacks for the next observation. All the stages of classroom observation, including the observation tools and the entire stage of observing the teaching process were completely decided upon by the supervisor. As the supervisor evaluated the teacher's performance, the teacher would defend him/herself concerning the given comments (Akbari et al., 2006). In such a situation, the observation of the teaching process did not significantly contribute to the teacher's professional improvement. As this kind of observation primarily aimed at empowering the supervisor while judging the teacher, this made the teachers dissatisfied. In the same vein, Gebhar (1990), Brown (1995), and Stroller (1996) conducted a study on the reasons for the teachers' fright during the classroom observation and found that this attitude is rooted in the traditional relationships between the teachers and the supervisor in which personal and unsystematic observations done without the teacher's awareness. These observations are observer-centered, authoritative, and directive; they are, in fact, done with the aim of judging the teacher. This kind of feedback leads to the passive role of the teacher in the education system. Therefore, teachers do not enter the decision-making process, and they do whatever they are told by the observer as such. To overcome this shortcoming, a classroom observation model was presented; the main aim of which was to strengthen the role of the teacher in the classroom (Brown, 1995). This model of classroom observation is teacher-oriented in which the teacher and observer exchange comments about the techniques of language teaching (Stroller, 1996).

Nowadays, supervisors plan to observe the teaching process without judging the teacher. In this view, the main goal of observing the teaching process is not to distinguish between "good" and "bad" teaching, but to identify the existing limitations along with the positive aspects of teaching (Stroller, 1996). Overall, observing the teaching process improve teacher's critical thinking ability and teaching performance (Stroller, 1996).

Thus, an appropriate observation paves the way for reaching the goals of teacher training courses. Therefore, English language institutes having an experienced and efficient supervisor usually have more successful teachers (Edmonds, 1979), because the supervisor has a significant impact on teacher's attitude, creativity and decision-making. Moreover, the collaboration between teachers and supervisors is one of the factors which affect the quality of supervision (Cogan, 1973). The cooperation of language teachers and supervisors leads to more effective teaching performance, because both parties listen to their thoughts and decisions and decide together (Moradi, Sepehrifar, \& Khadiv, 2014). Through regular classroom observations, the teachers are informed about the nature of class management techniques and their own teaching methodology. Accordingly, teachers become more efficient and effective.

\subsection{The Roles and Activities of Supervisors}

Supervisors play a key role in teachers' professional teaching performance. Supervisors have different roles 
aimed at improving the performance of teachers and success of the educational system (Farea, 2013). In a sense, the roles and responsibilities of the supervisor differ depending on the quality improvement of teachers' training program along with the teaching-learning process (Baniabdelrahman, 2004). As such, supervisors should be fully aware of the role they have when observing and evaluating the teaching process. Among the roles supervisors have in language institutes are resource person, adviser, morale booster, interpreter of feedback and assessor (Gujjar, Ramzan, \& Bajwa, 2011). Acheson \& Gall (1997) introduced other different roles for supervisors including, mentor, counselor, coach, cooperating teacher, inspector and leader. In addition, Koç (2008) describes the supervisor's roles as follows:

1) Interacting and cooperating with the cooperating teacher to design the teacher's course program; 2) Investigating the teacher's lesson plan; 3) supervising the teacher to explain the course program and class management; 4) describing different teaching methodologies to the teacher; 5) observing the teacher's performance during the teaching process at least twice a term; 6) oral and written comments and recommendations made about the teacher's teaching performance; 7) supervising the teacher to put his/her teaching knowledge into practice; 8) holding weekly conferences with teachers in order to discuss his/her own experiences; 9) guiding the teachers as a counselor; 10) exchanging ideas with teachers on new ideas and innovations; 11) completing the assessment form per lesson presentation; and 12) determining the teacher's final score with the help of the cooperating teacher.

\subsection{Models of Observation}

Many researchers have emphasized the important role of supervisors in the education system. In this sense, Hunter (1980) argues that if the heads of language institutes and also supervisors can cooperate and negotiate with their teachers as much as they expect the teacher to work with the students, there are greater chances for more efficient supervisors in our education system. Accordingly, to increase the quality of teaching and promote the knowledge of supervisors, different models and approaches were proposed for classroom observation. Freeman (1982) offers three approaches to teacher observation: 1) supervisory approach, 2) alternative approach, 3) non-directive approach. In the supervisory approach, the person who observes the class is the head of the institute or the supervisor. In this approach, the supervisor is seen as a powerful individual. To put it simply, one of the main points of this approach is an imbalance in the power relations between the teacher and supervisor. The supervisor evaluates the teacher's methodology and makes some suggestions for improving his/her teaching performance. The supervisor even provides some suggestions for the lesson plan, class management and seating arrangements (Freeman, 1982). Then, in the alternative approach Freeman (1982) introduces the supervisor as an individual who observes the teaching process without judging the teacher. Finally, in the non-directive approach the supervisor attempts to understand the teacher's practice and goals. In this approach, the supervisor acts as a supporter for the teacher. The supervisor does not aim to judge and evaluate the teacher, but observe the teaching process to help the teacher, instead. In other words, the supervisor helps the teacher to think more deeply about his/her teaching performance and evaluate it by himself/herself. In this approach, the emphasis is put on the importance of the functional role of supervisors, because the aim of the supervisor is to stimulate critical thinking in the teacher, which results in the improvement of the teacher's performance in future sessions (Sandbrook, 1996).

Gebhard (1984) develops Freeman's model and suggests five theoretical models for supervising and observing the teaching process: 1) directive supervision; 2) alternative supervision; 3) collaborative supervision; 4) non-directive supervision; 5) creative supervision. The role of the supervisor in the directive supervision model is to guide and inform, present the teaching methods, and evaluate the teacher's performance (Gebhard, 1984). In the alternative supervision model, the supervisor presents an alternative teaching method with the goal of increasing the performance domain of the teacher so that the teacher can use them based on the students' needs (Gebhard, 1984.). In the non-directive supervision model, the supervisor listens to the teacher's explanations about his/her teaching methodology without having the intention of judging. In this approach, the sole objective of observation is not to evaluate the teaching methodology of the teacher, but to encourage him/her for self-exploration (Fanselow, 1988). However, if the observation is only aimed at evaluating teachers, it would not have a significant effect on their performance (Fanselow, 1988). Therefore, the main goal of the supervisor is to help the teacher to start to gain knowledge and then create his own knowledge as such. In the collaborative supervision model, the main aim of the supervisor is the mutual understanding and the establishment of a relationship with the teacher (Gebhard, 1984). Finally, the creative supervision model is a combination of different supervision models that the supervisor uses in order to promote his/her performance.

In Goldsberry's approach (1988), three models are introduced for the role of the supervisor as follows: 1) nominal model; 2) prescriptive model; and 3) reflective model. Goldsberry (1988) argues that the main objective 
of nominal model is to be aware of the teaching procedure, supporting insiders, and retaining the existing educational context. According to Goldsberry (1988), this kind of supervision may be occasionally used when time is limited and the supervisor has not gained the knowledge and skills required for this profession. In the corrective supervision model, the main aim is to detect the educational problems and improve the current situation. Goldsberry (1988) considers the supervisor-teacher relation as the doctor-patient relation. In this context, the doctor prescribes medicine based on the observed symptoms in the patient, examines him/her, increases the dose of the medicine if necessary, talks to the experts in this field, and waits until the patient feels well. Hence, the supervisor has a great skill and knowledge in detecting the problems. In the reflective supervisor model, the supervisor is an individual who guides the teacher towards thinking more deeply about their teaching methods and techniques (Goldsberry, 1988).

Wallace (1991) also defines the prescriptive approach and collaborative approach for the role of supervisors at language institutes. In the prescriptive approach, the supervisor is an authority who judges teachers' skills. In the collaborative approach, the supervisor, as a colleague, attempts to listen to the teacher carefully and help him/her to act independently in making important decisions. According to Wallace (1991), supervisors will have an important role in improving the teacher's performance using the collaborative approach.

Jones (1995) brought up the democratic supervision approach based on the different definitions presented for the supervisor. According to Jones, the democratic supervision approach has the potential to positively affect the professional performance of language teachers and to promote the quality of instruction significantly. Democratic supervision is based on three principles: 1) the supervisor is an authority who solves the teachers' problems; 2) The discussion and negotiation between the teacher and supervisor are of great importance; 3) the negotiation between the supervisor and teachers must aim at selecting the most effective teaching methodologies and supervisory approaches.

The differences in the approaches for observing the teaching process has led to the confusion of observation among supervisors. Hence, Freeman (1982) recommends that the supervisors mostly use direct approaches for observing the teachers' performance with little experience while using an alternative approach for observing the experienced teachers' performance.

\subsection{Classroom Observation in the Language Institutes in Iran}

In many language institutes in Iran, the current procedures of teaching observations are described in the following. The applicants are trained in teaching training courses for one to two weeks. If the applicants possess the necessary characteristics in the view of the supervisors, they participate in one of the experienced teachers' classroom and observe his/her teaching process to become acquainted with the educational system of the institute and gain experiences in handling the classroom context. In addition, in many language institutes the applicant teacher should hold an IELTS or TOEFL certificate. Moreover, in this educational system the applicants demonstrate their practical skills after the training course. The first classroom experience of the teachers is observed by the supervisor in which the potential of the teacher is determined according to the observation checklist. In this check list, three important factors are considered by the supervisor: 1) teacher's personality traits; 2) technical characteristics; and 3) the teacher's language proficiency (Moradi, Sepehrifar, \& Khadiv, 2014). Accordingly, the teachers who successfully pass this stage are given permission to teach at a given language institute. Afterwards, the teachers' performance in the classroom is observed at least once during the term, and other items are also analyzed, including the teachers' ability in motivating the students to learn, the methodology of evaluating the students, teacher feedback, and the teacher's language proficiency. It is worth mentioning that the teacher receives a score for each of these items as such (e.g., effective \& acceptable teaching, promotable teaching, \& no progress in teaching).

Classroom observation has not yet occupied the place it deserves at language institutes in Iran. Despite the fact that supervisors along with the observation of the teaching process have significant roles in teacher education programs, there is only little information in this regard. Therefore, the aim of the current study was to investigate the Iranian EFL teachers' awareness of classroom observation criteria. In addition, we studied whether gender, age, teaching experience, education level, and teachers' major have an impact on their awareness of classroom observation criteria. We hope that this study paves the way for further studies and investigations to be carried out in this field, and that it ultimately results in the improvement of language teaching. In particular, the current study aimed to answer the following research questions:

1) What is the Iranian EFL teachers' awareness of classroom observation criteria?

2) Do teaching experience, university major, education level, and age affect the teachers' awareness of classroom observation criteria? 
3) Does gender affect the teachers' awareness of classroom observation criteria?

\section{Method}

\subsection{Participants}

The participants in this study consisted of 123 Iranian EFL teachers teaching in different language institutes and universities located in Bojnord, Mashhad, Neishabur, Quchan, and Torbat-e-Heidarieh, districts of Khorasan Razavi, Iran. They were 63 females and 60 males with less than five to more than ten years of teaching experience. The investigators selected $123 \mathrm{EFL}$ teachers by the convenience sampling. The teachers had BA, MA, or $\mathrm{PhD}$ degrees in different fields of study in English, including English literature, TEFL, translation studies, and linguistics. The English teachers all have different teaching certificates such as FCE, CAE, CPE, IELTS, and TOEFL.

The latter group of participants was 12 EFL teachers comprising female and males, who were teaching at different language institute in Mashhad, Neishabur and Torbat-e-Heydarieh, districts of Khorasan Razavi, Iran. The participants were selected by convenience sampling technique. Their teaching experience ranged from 2 to 16 years. The participants had BA, MA and PhD degree in English Literature, TEFL, and Translation Studies. Teachers' age ranged from 20 to 34 years. For the case of analysis, they were allowed to share their ideas in whichever language they preferred (English or Persian). They were ensured about the confidential nature of this study and were told with their consent, their voices would be fully recorded for later transcription and analysis. The recorded interviews were transcribed by researchers and analyzed.

\subsection{Instrumentation}

Interview and questionnaire were used for collecting the required data in this study.

\subsubsection{Questionnaire}

In order to obtain the necessary data for designing and developing the questionnaire, the authors examined the observation checklists of several language institutes. According to the classified criteria at four levels in the observation checklists of the institutes, a 39-item questionnaire was developed. Six items were concerned with the teachers' awareness of language proficiency and appearance criterion; ten items were related to the teachers' awareness of the class management and organization criterion. Thirteen items were concerned about the teachers' awareness of teaching techniques and lesson presentation criterion, whereas ten items were related to the observation criteria of teacher-student interaction and motivating students for learning. The questionnaire was on a Likert- type scale, consisting of five scales ranging from $1=$ not at all aware to $5=$ extremely aware. The teachers' awareness was qualitatively divided into five categories. Obtaining a minimum of $81 \%$ of the score was considered extremely aware. Moderately aware was considered as score between $61 \%-80 \%$, somewhat aware $41 \%-60 \%$, slightly aware $21 \%-40 \%$, and not at all aware $0 \%-20 \%$. To determine the content validity of the questionnaire, it was given to three faculty members at the TEFL department at Islamic Azad University, and some of their comments were used to improve the items. The questionnaire was piloted with $30 \mathrm{EFL}$ teachers in order to obtain information regarding the relevance and clarity of the questions, format, and time of allotment. They were then revised accordingly. The questionnaire enjoyed a high reliability of 0.96 Cronbach's alpha coefficient, which was indicating acceptable internal consistency. Meanwhile, the data were gathered in person and through email.

\subsubsection{Interview}

The researchers with the aid of the supervisor interviewed with 12 EFL teachers to cross-check teachers' responses to the questionnaire and to find out more information on their responses which was not possible in the questionnaire. Hence, interview questions contained two items:

1) Which criteria are used in assessing teacher performance in observation session?

2) What do you like to be observed in your classes?

\subsection{Data Analysis Procedures}

The data obtained through the questionnaire were analyzed on the computer by using Statistical Package for the Social Sciences (SPSS) version 21. Using descriptive statistics (mean, standard deviation, frequency, \& percentage), independent samples t-test, and ANOVA test, the data were analyzed.

\section{Results}

\subsection{Questionnaire}

The criteria used for classroom observation were divided into four levels: 1) The criteria of teacher's language 
proficiency and appearance; 2) the criteria of class management and organization; 3) the criteria of teaching technique and lesson presentation; 4) the criteria of teacher-student interaction and motivating students for learning. In the following sections, the results of each of these observation criteria are presented:

\subsubsection{The Criteria of Teacher's Language Proficiency and Appearance}

After investigating the teachers' awareness score of the observation criteria of language proficiency and appearance, it was found that the mean score for this criterion was 24.96 while the standard deviation was 4.92 . In the current study, 76 teachers $(61.8 \%)$ were extremely aware, 31 teachers $(25.2 \%)$ were moderately aware, 11 teachers $(8.9 \%)$ were somewhat aware, and 5 teachers $(4.1 \%)$ were slightly aware. The independent samples t-test indicated that there was not a statistically significant difference between gender and teachers' awareness of the observation criteria of language proficiency and appearance $(\mathrm{p}=0.124)$.

\subsubsection{The Criteria of Class Management and Organization}

The results indicated that the mean awareness score in the observation criteria of class management and organization was 40.46 with a standard deviation of 7.20 . Overall, 69 teachers (56.1\%) were extremely aware, 39 teachers $(31.7 \%)$ were moderately aware, 14 teachers $(11.4 \%)$ were somewhat aware, and one teacher $(0.8 \%)$ was slightly aware. The results of the independent samples t-test revealed that the significant difference was not found between gender and the teachers' awareness of the observation criterion of class management and organization $(\mathrm{p}=0.119)$.

\subsubsection{The Criteria of Teaching Techniques and Lesson Presentation}

With regard to the teachers' awareness of the observation criterion of the teaching techniques and lesson presentation, the mean awareness of the samples was 54.40 with a standard deviation of 8.92 . More particularly, 82 teachers $(66.7 \%)$ were extremely aware, 34 teachers $(27.6 \%)$ were moderately aware, 6 teachers $(4.9 \%)$ were somewhat aware, and one teacher $(0.8 \%)$ was slightly aware. The independent samples t-test indicated that there was not a significant difference between gender and the teachers' level of awareness of the observation criteria of teaching techniques and lesson presentation $(\mathrm{p}=0.402)$.

\subsubsection{The Criteria of Teacher-Student Interaction and Motivating Students for Learning}

Based on the analysis, the mean awareness score of teachers for the observation criteria of teacher-student interaction and motivating students for learning was 39.76 while the standard deviation was 7.45 . In other words, 55 teachers $(44.7 \%)$ were extremely aware, 51 teachers $(41.5 \%)$ were moderately aware, 16 teachers $(13 \%)$ were somewhat aware, and one teacher $(0.8 \%)$ was slightly aware. The independent samples t-test showed that there was not a significant difference between male and female teachers regarding their awareness of the observation criteria of teacher-student interaction and motivating students for learning $(\mathrm{p}=0.922)$.

Based on the obtained results, the mean awareness score of English language teachers from the total of 39 items related to the criteria of teaching observation was 159.5 with a standard deviation of 19.65 . In other words, 76 teachers $(61.8 \%)$ were extremely aware, 46 teachers $(37.4 \%)$ were moderately aware, and one teacher $(0.8 \%)$ was somewhat aware. Following the investigation of the teachers' teaching experience, 6 teachers with less than five years of teaching experience (40\%), 24 teachers with 5-10years of teaching experience $(55.8 \%)$, and 46 teachers with more than ten years of teaching experience (70.8\%) were extremely aware. However, it seems that the more experience the teachers gain, the more aware they become of the observation criteria. Based on the findings of the current study, for the male group 30 individuals (50\%) were extremely aware while 30 teachers $(50 \%)$ were moderately aware. As for the female group, 46 teachers $(73 \%)$ were extremely aware, 16 teachers (25.4\%) were moderately aware, and one teacher (1.6\%) was somewhat aware. Based on the independent samples t-test, there was no statistically significant difference between gender and the teachers' awareness variables $(\mathrm{p}=0.417)$. In a nutshell, the results of the teachers' awareness of the classroom observation criteria in terms of teaching experience are presented in Table 1. 
Table 1. The frequency of the teachers' awareness of classroom observation criteria in terms of teaching experience

\begin{tabular}{|c|c|c|c|c|c|c|c|c|c|c|}
\hline \multirow[t]{2}{*}{$\begin{array}{l}\text { Evaluating } \\
\text { Teacher } \\
\text { Awareness }\end{array}$} & \multicolumn{2}{|c|}{ High awareness } & \multicolumn{2}{|c|}{ Partial awareness } & \multicolumn{2}{|c|}{$\begin{array}{l}\text { Awareness to a certain } \\
\text { extent }\end{array}$} & \multicolumn{2}{|c|}{ Low awareness } & \multicolumn{2}{|c|}{ No awareness } \\
\hline & frequency & percentage & frequency & percentage & frequency & percentage & frequency & percentage & frequency & percentage \\
\hline $\begin{array}{l}\text { Less than } 5 \text { years } \\
\text { of teaching } \\
\text { experience }\end{array}$ & 6 & $40 \%$ & 9 & $60 \%$ & - & - & - & - & - & - \\
\hline $\begin{array}{l}5 \text { to } 10 \text { years of } \\
\text { teaching } \\
\text { experience }\end{array}$ & 24 & $55.8 \%$ & 18 & $41.9 \%$ & 1 & $2.3 \%$ & - & - & - & - \\
\hline $\begin{array}{l}\text { More than } 10 \\
\text { years of teaching } \\
\text { experience }\end{array}$ & 46 & $70.8 \%$ & 19 & $29.2 \%$ & - & - & - & - & - & - \\
\hline
\end{tabular}

The results of the teachers' awareness of the assessment criteria in classroom observation can be seen in Table 2 .

Table 2. The teachers' awareness of classroom observation criteria

\begin{tabular}{|c|c|c|c|c|c|c|c|c|c|c|}
\hline \multirow{2}{*}{$\begin{array}{l}\text { Criteria for the } \\
\text { Observation of } \\
\text { Teaching Process }\end{array}$} & \multicolumn{2}{|c|}{ High awareness } & \multicolumn{2}{|c|}{ Partial awareness } & \multicolumn{2}{|c|}{$\begin{array}{l}\text { Awareness to a certain } \\
\text { extent }\end{array}$} & \multicolumn{2}{|c|}{ Low awareness } & \multicolumn{2}{|c|}{ No awareness } \\
\hline & frequency & percentage & frequency & percentage & frequency & percentage & frequency & percentage & frequency & percentage \\
\hline $\begin{array}{l}\text { Teacher's } \\
\text { language } \\
\text { proficiency and } \\
\text { appearance }\end{array}$ & 76 & $61.8 \%$ & 31 & $25.2 \%$ & 11 & $8.9 \%$ & 5 & $4.1 \%$ & - & - \\
\hline $\begin{array}{l}\text { Class } \\
\text { management and } \\
\text { organization }\end{array}$ & 69 & $56.1 \%$ & 39 & $31.7 \%$ & 14 & $11.4 \%$ & 1 & $0.8 \%$ & - & - \\
\hline $\begin{array}{l}\text { Teaching } \\
\text { technique and } \\
\text { lesson } \\
\text { presentation }\end{array}$ & 82 & $66.7 \%$ & 34 & $27.6 \%$ & 6 & $4.9 \%$ & 1 & $0.8 \%$ & - & - \\
\hline $\begin{array}{l}\text { Teacher-student } \\
\text { interaction and } \\
\text { motivating } \\
\text { students for } \\
\text { learning }\end{array}$ & 55 & $44.7 \%$ & 51 & $41.5 \%$ & 16 & $13 \%$ & 1 & $0.8 \%$ & - & - \\
\hline
\end{tabular}

In order to investigate the effect of majors on the teachers' awareness of the classroom observation criteria, one-way ANOVA was conducted. Table 3 includes the summary of the ANOVA test in terms of the teachers' awareness and majors.

Table 3. The summary of the ANOVA test for the teachers' awareness and majors

\begin{tabular}{llllll}
\hline & Sum of Squares & df & Mean Squares & F & Sig. \\
\hline Between Groups & 793.261 & 3 & 264.420 & .679 & .567 \\
Within Groups & 46358.593 & 119 & 389.568 & & \\
\hline
\end{tabular}

The results of the ANOVA test conducted for the majors (i.e. teaching, translation, literature, and so forth) indicated that the difference of means was not significant $(\mathrm{F}=0.679, \mathrm{P}=0.567)$. In other words, the university major does not have a significant impact on the teachers' awareness level.

To investigate the effects of education level on the teachers' awareness of the observation criteria, one-way ANOVA was used. Table 4 represents the summary of the ANOVA test for the teachers' awareness and education level. 
Table 4. The summary of the ANOVA test for the teachers' awareness and education level

\begin{tabular}{llllll}
\hline & Sum of Squares & df & Mean Squares & F & Sig. \\
\hline Between Groups & 1366.788 & 2 & 683.394 & 1.791 & .171 \\
Within Groups & 381.542 & 120 & 381.542 & & \\
\hline
\end{tabular}

The results of the ANOVA test regarding the education level (diploma, associate degree, BA, MA, PhD) showed that the difference of means was not significant $(\mathrm{F}=1.791, \mathrm{P}=0.171)$. In other words, the education level does not significantly affect the teachers' awareness level.

In order to investigate the effect of age on the teachers' awareness of the criteria used for classroom observation, one-way ANOVA was conducted. Table 5 includes a summary of the ANOVA test for the teachers' awareness and age.

Table 5. The summary of the ANOVA test for the teachers' awareness and age

\begin{tabular}{llllll}
\hline & Sum of Squares & df & Mean Squares & F & Sig. \\
\hline Between Groups & 3422.969 & 4 & 855.742 & 2.309 & .050 \\
Within Groups & 43.728 .885 & 118 & 370.584 & & \\
\hline
\end{tabular}

The results of the ANOVA test regarding age $(20-25,26-30,31-35, \& 36-40)$ indicated that the difference of means was significant $(\mathrm{F}=2.309, \mathrm{P}=0.050)$. In other words, the results showed that age a significant effect on the teachers' awareness of the observation criteria.

To find the accurate mean, a post-hoc test was also conducted. The results of the post-hoc test indicated that the significance level was less than 0.05 between the age groups of 20-25 and 26-30, 20-25 and 31-35, 20-25 and 36-40; therefore, the mean difference between these groups was significant.

\subsection{Interview}

The researchers interviewed with $12 \mathrm{EFL}$ teachers to reveal their specific ideas regarding their awareness of the observation criteria used in assessing their performance. As stated earlier interview questions contained two items. Interview questions were posed to each teacher. The researchers transcribed language teachers' responses to the questions as they heard from the utterances.

In response to Question 1 regarding which criteria are used in classroom observation, the vast majority of the teachers $(83 \%)$ were aware of most of classroom observation criteria. Moreover, it appears that more than half of teachers $(75 \%)$ strongly believed that supervisor as a professional helps them to be aware of the observation criteria. The teachers declared that supervisor encourages them to be aware of the important issues in the field of EFL teaching and helps teachers with improving their teaching. For instance some noted that:

...Actually I give enough importance to my professional development so I focus on every factor which my supervisor tells me to improve my teaching skills and knowledge...Supervisor makes me familiar with most important teaching evaluation criteria like: the use of classroom activities which develop the students listening, speaking and writing skills; the use of suitable teaching technique for students, and the use of other instructional aids for example video and overheads...

...I think that supervisor has a significant role for my professional development. Always he pays attention to important details that make me aware of every activity I design... classroom observation criteria which I familiar with are: the way teacher deals with the students varied behaviors; the way teacher uses methods to help students effectively and to overcome the difficulties that they face in learning, the way teacher treats the students' weakness; ... the way teacher summarizes major points of lesson and emphasizes important points, the way teacher monitors all students, the way the teacher encourages question and discussion,... Does the teacher use warm up activity and assign home work?

...Thank the supervisor who guides me with different techniques of classroom management...I am quite aware of all the classroom observation criteria used in checklist such as the teacher's skills in employing techniques; whether the teacher speaks, reads and writes English language correctly or not, I mean accuracy and fluency in language; whether the teacher models expected language use; whether the teacher uses examples to explain content; whether the teacher establishes and maintains eye contact with all students; and whether the teacher uses group work or pair work in each activity or not... 
In relation to Question 2 regarding what criteria do you like to be observed in your classes, nearly half of the teachers (58\%) highlighted the importance of establishing relationship with students as an observation criterion which should be added to the classroom observation checklist. In addition, for more than half of the teachers (75\%), the other important observation criterion which can be used for assessing teacher's performance is the amount of EFL teachers' creativity in the domain of teaching. What follows are some of the teachers' answers:

...Whether teachers establish positive relationship with the students and encourage them to express their ideas...

...Having friendly relationship with students which encourage them to ask more questions in order to seek better understanding of the content...

...How far can a teacher develop friendship and mutual respect in a classroom?...

...It's better the supervisor attention to the friendly relationship between teacher and students, and teacher's control over students at the same time...

...Creating an intimate atmosphere that could highly influence on students learning...

...The criteria relate to whether I stick to a teacher guide or am I able to creativity handle same tasks in a way that fits the unique context of my class...

...Evaluate teacher's creativity. I mean the teacher follows teachers' book and at the same time flexibility crates new ideas out of given ones which are for the class...

\section{Discussion and Conclusion}

As stated earlier in this paper, the aim of this study was to investigate the Iranian EFL teachers' awareness of the classroom observation criteria. The results indicated that nearly more than half of the teachers had a sufficient awareness of the observation criteria. The reason for such a finding may be related to the coordination and interaction between the teachers and supervisors and also the teachers 'due attention to the observation criteria. As can be seen, there was not a significant difference between the teachers' gender and awareness of observation criteria. However, high level of awareness was seen more among female teachers. The findings of this study are in line with findings of Al-Yaseen (2007), indicating that there were no significant difference between female and male teacher regarding their perceptions of the important role of supervisors in improving the teachers' performance, teachers' perception of gaining experiences from observing classes, teachers' perception of the nature of supervisor's classroom observation, and teachers' perception of the nature of teacher-supervisor relationships.

Although it was generally believed that, the participants' awareness of the observation criteria would be very high for the $\mathrm{PhD}$ education group due to the more specialized training and research in teaching principles and methodologies, the results of the ANOVA test did not indicate a significant difference between the teachers' education level and their awareness of classroom observation criteria. This result may be due to the fruitfulness of continuous training programs for all the teachers and also the repetition of pre-observation meeting and the briefing session between teachers and supervisor which can help increase teachers' awareness of the efficient teaching technique and supervisor's criteria for evaluating their performance. Contrary to our expectations, the results of the ANOVA test indicated that the teachers' field of study does not affect their awareness. This result might be due to the fact that all English students in different majors have courses related to teaching methodologies, which leads to sufficient knowledge and awareness of the criteria for effective teaching. Moreover, these results are partly due to reading books and research articles on teaching methodology, gaining experience in teaching, observing the teaching process by the supervisor, and observing the teaching process of other teachers. In addition, as a result of the interaction between the teacher and supervisor, teachers become familiar with the goal, method, and the criteria of observation. Moreover, in the briefing session after classroom observation, the observation report is carefully examined, and teachers become aware of the merits and demerits of their teaching method according to the observation assessment criteria. As such, the teachers' awareness level of the assessment criteria increases in this way. Based on the results of the ANOVA test, age had a significant impact on the teachers' awareness, which may indicate that older teachers, update their knowledge and awareness. The results of the descriptive test for the teachers' awareness of the classroom observation criteria with regard to teaching experience suggested that the awareness level of teachers with more than 10 years of teaching experience was more than the teachers with less than 5 years. This result might imply that working experience and aging process resulted in the teachers' mastery and increased awareness of the criteria for an effective teaching method. The aging of teachers, increased teaching experience, increasing sessions held between the supervisor and teachers during the academic year, and the feedback provided by the supervisor 
equip teachers with an experience which leads to an increase in their awareness of observation criteria. In addition, the result of interview showed there are some observation criteria should be added to the checklist including building positive teacher-student relationship and creating creative environment in the classrooms which could influence on students learning. Therefore, on the one hand, teachers should enhance their knowledge of creative teaching skills and technique which could develop and increase their creativity in teaching. On the other hand, this criterion should be considered in design of observation checklist. Hernandez \& Shewchuk (2013) have the same findings. They declared that the most important step in education process is teachers' creativity which enhances academic achievement of students (Hernandez \& Shewchuk, 2013). Hossaini (2008) also found that teachers' creativity has considerable relationship with improvement of students' creativity. According to Lakatos (1970) it is necessary for pre-service and in-service teachers to pass course about creativity. Hence, teachers should increase their awareness of creativity in teaching so as to create creative environment in the classrooms and help students to improve their learning. Moreover, according to the results of interview it can be concluded that if supervisors paying further notice to positive teacher-student relationship and add this item to the observation checklist and teachers be informed of this criterion, the quality of teaching and learning will be increased. Fan \& Willams (2010) came to the same conclusion. They declared that teacher-student relationship is crucial to motivate students to actively participate in classroom activities and enjoy learning (Fan \& Willams, 2010). Based on Hughes, Cavell and Jackson (2001) findings students who have a warm, secure and encouraging relationship with their teacher are more motivated to participate in class activities and improve their learning achievement. Hamre \& Pianta (2001) also concluded that when teachers have positive relationship with students, create encouraging and supportive classroom environment for them to improve academically and socially.

The results of the current study are in accordance with the results of study by Akbari, Gaffar, \& Tajik (2006). Akbari et al., (2006) found that the interaction between the teacher and supervisor in pre-observation meeting and the discussion occurs between two parties lead them to talk about lesson objectives, educational issues, the observation goals, the observation assessment criteria, the observation method, the method of documenting observations, and the presentation of feedback by the supervisor. Therefore, the teacher's awareness of his own teaching observation process increases, and they become more involved in classroom observations while their negative attitude towards observation is replaced by a positive approach (Akbari et al., 2006). In this sense, Zaare (2013) similarly concluded that the classroom observation session followed by the briefing session in which the teacher and supervisor discuss the ways for improving the teaching methodology, provides an opportunity for teachers to raise their awareness of the relation between the educational issues and teaching methodology. Thus, observing the teaching process along with the awareness of the observation criteria can act as a guide for teachers by which they can reflect on their teaching performance and come up with a better understanding about the observed criteria. As such, teachers may adopt a more functional teaching methodology (Zaare, 2013). Richards \& Farrell (2005) also found that the main objective of observing the teaching process is to gain experience. Accordingly, these sessions have an impact on the awareness and experience level of teachers. That is, more experienced teachers are more likely to be reflective and think about their performance, participate further in the decision-making process, and are generally more successful in teaching (Richards \& Farrell, 2005). According to the findings offered by Rahmany, Hasani, \& Parhoodeh (2014), the classroom observation along with the supervision of the teacher's performance plays an important role in the decision-making process of inexperienced teachers; since this group of teachers has a positive attitude towards the role of the supervisor. Moreover, the results of the current study are in line with the findings of Garrett \& Steinberg (2014). They found that teacher's performance is observed several times during an academic year through, as a result of which the teachers becomes aware of the act of observation and observation criteria. Given this awareness, teachers improve certain skills and methods, promote their teaching performance, and gain more useful working experiences. According to Rahmany et al. (2014), classroom observation and collecting information based on pre-determined assessment criteria given positive feedback to teachers, which leads to the improvement of the teachers' professional performance and the students' learning as a result. In a similar vein, Williams (1989) also discussed that if the main objective of observation is the improvement of the teaching performance and not making a judgment about their teaching method, it provides great opportunities for the teachers, which ultimately results in an increase in their awareness and ability to evaluate their own teaching method. In addition, Rahmany et al. (2014) argued that most teachers carefully read their observation report following the observation session and use the mentioned criteria in it for improving their teaching quality. Therefore, when the teachers' awareness of observation increase, the teachers are considered as the main authority in the observation process, and this change of approach lead to a big change in the act of observation (Akbari et al., 2006).

The awareness of the observation criteria for observation helps the teachers to have a better performance in the observation session. The findings of the current study may be of help to inexperienced EFL teachers or the 
teachers who are not fully aware of classroom observation criteria to use concrete and objective assessment criteria to assess their teaching performance and recognize their shortcomings. However, teachers should be trained to be able to use the results obtained from observation and apply them to their teaching techniques. Thus, teachers attain theoretical and practical knowledge to improve their teaching quality and promote the level of their teaching. As a result, students become more involved in the teaching process and their level of learning increases. Hence, in the future observation sessions the supervisor would recognize this improvement in students, give a better score to the teacher, and evaluate him/her as a successful teacher (Whitehurst, Chingos, \& Lindquist, 2015). On the other hand, in order to increase the effectiveness of observation and the efficiency of teaching, the supervisors should also get familiar with the condition in which the teacher works; in case of noticing a drawback in the teacher's performance, supervisors should express their criticisms with a professional, friendly, and respectful behavior; supervisors should explain the observation criteria and observation process to the teacher accurately (Moradi, Sepehrifar, \& Khadiv, 2014). Therefore, teachers have the opportunity to share their thoughts with the supervisors in this way (Moradi et al., 2014). Finally, it is recommended that a mixed-methods study be conducted in terms of teachers' awareness of the observation criteria collecting further data through questionnaires, interviews, and classroom observations.

\section{Acknowledgments}

We are particularly grateful to all EFL teachers who participated in the research. We would like thank our friend and colleague, Mona Tabatabaee Yazdi, for supporting and encouraging us to keep focused.

\section{References}

Acheson, K., \& Gall, M. D. (1997).Techniques in the clinical supervision of teachers: Preservice and inservice applications (4th ed.). New York: Longman.

Akbari, R., Gaffar, S. R., \& Tajik, L. (2006). Developing a classroom observation model based on Iranian EFL teachers' attitude. Journal of Faculty of Letters and Humanities, 49(198), 1-37.

Allwright, D. (2014). Observation in the language classroom. London: Routledge.

Al-Yaseen, W. S. (2007). EFL teachers' perceptions of the professional role of EFL educational supervisors in Kuwait intermediate schooldds. The Educational Journal, 21, 11-53.

Baniabdelrahman, A. A. (2004). Roles of cooperating teachers and practicum supervisors and their effect on EFL student-teachers' teaching skills. Asian EFL journal, 6(3).

Brown, J. L. (1995). Observing dimensions of learning in classrooms and schools. Alexandria .VA: Association for Supervision and Curriculum Development.

Cogan, M. L. (1973). Clinical supervision. Boston: Houghton-Mifflin.

Cohen, L., Manion, L., \& Morrison, K. (2000). Research methods in education (5th ed.). London: Routledge Falmer. http://dx.doi.org/10.4324/9780203224342

Edmonds, R. R. (1979). Some schools work and more can. Social policy, 9(5), 28-32.

Fan, W., \& Williams, C. M. (2010). The effects of parental involvement on students' academic self-efficacy, engagement and intrinsic motivation. Educational Psychology, 30(1), 53-74. http://dx.doi.org/10.1080/01443410903353302

Fanselow, J. F. (1988). "Let's see”: contrasting conversations about teaching. TESOL Quarterly, 22(1), 113-130. http://dx.doi.org/10.2307/3587064

Farea, Q. D. A. (2013). EFL Teachers' perception of the professional role of EFL educational supervisors in Yemeni Secondary Schools. Journal of Education Science, 21(1).

Freeman, D. (1982). Observing teachers: Three approaches to in-service training and development. TESOL Quarterly, 16(1), 21-28. http://dx.doi.org/10.2307/3586560

Garrett, R., \& Steinberg, M. (2015). Examining teacher effectiveness using classroom observation scores: Evidence from the randomization of teachers to students. Educational Evaluation and Policy Analysis, 37(2), 224-242. http://dx.doi.org/10.3102/0162373714537551

Gebhard, J. G. (1984). Models of supervision: Choices. TESOL Quarterly, 501-514. http://dx.doi.org/10.2307/3586717

Gebhard, J. G. (1990). Models of supervision: Choices. In J. C. Richards \& D. Nunan (Eds.), Second Language Teacher Education (pp. 156-167). Cambridge: Cambridge University Press. 
Goldsberry, L. (1988). Three functional methods of supervision. Action in Teacher Education, 10(1), 1-10. http://dx.doi.org/10.1080/01626620.1988.10519369

Gujjar, A. A., Ramzan, M., \& Bajwa, M. J. (2011). An evaluation of teaching practice: practicum. Pakistan Journal of Commerce and Social Sciences, 5(2), 302-318.

Hamre, B. K., \& Pianta, R. C. (2001). Early teacher-child relationships and the trajectory of children's school outcomes through eighth grade. Child Development, 72(2), 625-638. http://dx.doi.org/10.1111/1467-8624.00301

Hernandez, S. R., \& Shewchuk, R. M. (2013). Innovative teaching methods and content for health administration education. The Journal of Health Administration Education, 30(1).

Hosseinee, A. (2008). Investigating the impact of the creativity teaching program on teachers' knowledge, attitude, and skills. Journal of Educational Innovations, 22, 67-72.

Hughes, J. N., Cavell, T. A., \& Willson, V. (2001). Further support for the developmental significance of the quality of the teacher-student relationship. Journal of School Psychology, 39(4), 289-301. http://dx.doi.org/10.1016/S0022-4405(01)00074-7

Hunter, M. (1980). Six types of supervisory conferences. Educational Leadership, 37(5), 408-412.

Kimbrough, R. B., \& Burkett, C. W. (1990). The principalship: Concepts and practices. Englewood Cliffs, NJ: Prentice-Hall.

Koç, E. M. (2008). An investigation of cooperating teachers' roles as mentors during the teaching practicum at distance BA program in ELT at Anadolu University Open Education Faculty. Unpublished Ph. D, Anadolu University, Eskişehir.

Lakatos, I. (1976). Falsification and the methodology of scientific research programmes. Can Theories be Refuted? (pp. 205-259). Springer Netherlands. http://dx.doi.org/10.1007/978-94-010-1863-0_14

Mackey, A., \& Gass, S. (2005). Second language research: Methodology and design. Mahwah NJ: Lawrence Erlbaum.

Moradi, K., Sepehrifar, S., \& Khadiv, T. P. (2014). Exploring Iranian EFL teachers' perceptions on supervision. Procedia-Social and Behavioral Sciences, 98, 1214-1223. http://dx.doi.org/10.1016/j.sbspro.2014.03.536

Rahmany, R., Hasani, M. T., \& Parhoodeh, K. (2014). EFL teachers' attitudes towards being supervised in an EFL context. Journal of Language Teaching and Research, 5(2), 348-359. http://dx.doi.org/10.4304/jltr.5.2.348-359

Richards, J. C., \& Farrell, T. S. C. (2005). Professional development for language teachers: Strategies for teacher learning. Ernst Klett Sprachen. http://dx.doi.org/10.1017/CBO9780511667237

Sandbrook, I. (1996). Making Sense of Primary Inspection. Buckingham: Open University Press.

Shantz, D., \& Brown, M. (1999). Developing a positive relationship: The most significant role of the supervising teacher. Education, 119(4), 693-693.

Sheal, P. (1989). Classroom observation: training the observers. ELT journal, 43(2), 92-104. http://dx.doi.org/10.1093/elt/43.2.92

Stoller, F. (1996). Teacher supervision: Moving towards an interactive approach. English Teaching Forum, 34(2), 2-9.

Wallace, M. J. (1991). Training foreign language teachers: A reflective approach. Cambridge: Cambridge University press.

Whitehurst, G., Chingos, M. M., \& Lindquist, K. (2015). Getting classroom observations right. Education Next, $15(1), 62-68$.

Widodo, H. P., \& Zakaria, F. (2008). Language teacher supervision: A case-based approach. Reading, 8(1).

Williams, M. (1989). A developmental view of classroom observations. ELT Journal, 43(2), 85-91. http://dx.doi.org/10.1093/elt/43.2.85

Zaare, M. (2013). An investigation into the effect of classroom observation on teaching methodology. Procedia-Social and Behavioral Sciences, 70, 605-661. http://dx.doi.org/10.1016/j.sbspro.2013.01.099 


\section{Copyrights}

Copyright for this article is retained by the author(s), with first publication rights granted to the journal.

This is an open-access article distributed under the terms and conditions of the Creative Commons Attribution license (http://creativecommons.org/licenses/by/4.0/). 